\title{
Do RESPEITO ÀS DECISÕES DO STF E A SÚMULA VINCULANTE
}

\author{
The compliance with the decisions of Supreme \\ Court and the stare decisis principle
}

\section{Thiago Rodovalho dos Santos}

Mestre em Direito Civil e Doutorando em Direitos Difusos e Coletivos pela PUC-SP. Professor de Direito Civil e Filosofia do Direito do Instituto Superior de Ciências Aplicadas (Isca) de 2005 a 2008. Palestrante convidado no Cogeae - PUC-SP (Professor-Mestre). Membro da OAB-SP, OAB-DF, AASP, do Instituto Brasileiro de Direito de Família (IBDFAM), da Associação Brasileira de Ensino do Direito (Abedi) e do Conselho Nacional de Pesquisa e Pós-graduação em Direito (Conpedi). Advogado.

Recebido em: 25.11.2011 Aprovado em: 23.01.2012

ÁreA do DIREITo: Constitucional; Processual

Resumo: 0 presente trabalho visa a analisar o polêmico instituto da súmula vinculante no ordenamento jurídico brasileiro. Tema que suscita calorosos debates e é, constantemente, acusado de tolher o magistrado em seu livre convencimento, além de engessar a jurisprudência. Pretendemos demonstrar que tais críticas não procedem. E mais, que a súmula vinculante vem em boa hora, como forma de racionalizar o discurso jurídico, dar mais efetividade às decisões do STF, conferindo mais segurança, isonomia e celeridade ao nosso sistema jurídico.

\begin{abstract}
АвSTRACT: This work pretends to study the controversial institute of Stare Decisis in the Brazilian legal system. This topic raises heartfelt discussions, and it is constantly accused of taking from the judge his free conviction, in addition to crystallize the jurisprudence. We want to demonstrate that such criticisms are not correct. Moreover, the Stare Decisis is binding in good time, as a way to streamline the legal discourse, to give more effectiveness to the decisions of the Supreme Court, with more security, parity and speed to our legal system.
\end{abstract}


Palavras-chave: Jurisprudência - Segurança jurídica - Previsibilidade - Autoridade - Precedente.
KeYWORDS: Jurisprudence - Law security - Predictability - Authority - Precedents.

SumÁRIO: 1. Introdução - 2. Considerações iniciais - 3. 0 problema da morosidade da Justiça - 4. 0 problema da segurança juridica e da previsibilidade das decisões judiciais - 5 . A necessidade do respeito à autoridade - 6 . Matérias que podem ser objeto de súmula vinculante - 7. A súmula vinculante engessa a jurisprudência? - 8. E em caso de descumprimento? - 9. Conclusão - 10. Referências bibliográficas.

\section{INTRODUÇÃO}

Com o advento da EC 45/2004, que promoveu uma reforma do Judiciário, restou instituída em nosso ordenamento jurídico a súmula vinculante (ou súmula com efeito vinculante), instituto este que passou a integrar a própria Constituição Federal, em seu art. 103-A e parágrafos, que posteriormente foi regulamentado pela Lei 11.417/2006.

Poucos temas têm produzido tão intensos e calorosos debates, seja no polo favorável, seja no polo contrário, como a instituição da referida súmula vinculante, ${ }^{1}$ promovendo uma divisão na doutrina.

Se temos, de um lado, aqueles que se posicionam favoravelmente à adoção da súmula vinculante, em entendimento aparentemente majoritário; do outro, entre aqueles contrários à sua adesão, temos também parcela não pequena da doutrina, entre os quais figuram, por exemplo, Evandro Lins e Silva, Renato Nalini e Luiz Flávio Gomes. Lados que se digladiam e ambos com bons e importantes argumentos.

Em razão disso, pontuam, com acerto, Luiz Rodrigues Wambier et al, que:

1. Neste sentido, Rodolfo de Camargo Mancuso: "Poucos temas terão suscitado tamanha controvérsia e entrincheirado em polos opostos tão ferrenhos adversários, como o da súmula vinculante, agora positivada na Carta Constitucional, não em modo pioneiro, como antes visto, mas num contexto de ordenação sistemática e ampliativa da matéria. Não seria exagerado, ante a acentuada conflituosidade despertada pelo tema, colocá-lo no patamar de outros assuntos igualmente polêmicos, propícios a infindáveis discussões, como a liberação do aborto, a pena de morte, o Júri popular, a diminuição da idade para responsabilidade penal, guardadas as devidas proporções" (Súmula vinculante e a EC n. 45/2004. In: Arruda Alvim Wambier, Teresa (coord.) et al. Reforma do Judiciário - Primeiras reflexões sobre a Emenda Constitucional $n$. 45/2004. São Paulo: Ed. RT, 2005. Cap. LII, p. 706). 
"A perspectiva da adoção do sistema da súmula vinculante em nosso país sempre nos preocupou e a toda comunidade jurídica. Parece impossível, todavia, à questão, no sentido de ser positiva (vantajosa) a adoção desse sistema, responder pura e simplesmente, do modo lacônico, sim ou não."2

De fato, razão lhes assiste. Neste debate, embora ele se situe num campo de imbricadas paixões, é preciso sopesar os prós e os contras, as vantagens e desvantagens da adoção deste sistema, para somente então concluir-se ser ele positivo ou não. Tentando evitar, deste modo, que, cegos pelas paixões, formulemos aquele lacônico "sim" ou aquele lacônico "não", imaginando um estado ideal de coisas que na prática, infelizmente, não existe. Logo, é preciso atentar-se para a realidade da situação do Judiciário e do nosso ordenamento jurídico, bem como para a imagem que os jurisdicionados têm deles. De nada adianta continuarmos pensando e falando em um modelo ideal e irrealista de Judiciário, olvidando-se das mazelas e problemas que diuturnamente a realidade lança, cruamente, à nossa face.

É preciso enfrentar a realidade e tentar buscar um modelo que sirva mais aos anseios da população, resgatando o prestígio e a confiança no Judiciário como um todo (pensando em todos os seus atores: juízes, advogados e Ministério Público), conferindo-lhe a celeridade, segurança e previsibilidade de que tanto ele necessita.

Este é, sem dúvida, ao lado da Justiça, o quadrinômio sobre o qual deve estar erigido o Judiciário: justiça, celeridade, segurança e previsibilidade.

Pensar em Justiça, sem celeridade, é uma contradictio in terminis. Onde há morosidade, ali não pode residir a Justiça.

E pensar em um Poder Judiciário que em sua organicidade hierárquica não transmita segurança e previsibilidade de suas decisões, seria chancelar o caos que esta insegurança jurídica traz aos jurisdicionados, situação esta que é contrária aos ditames não só do justo, como também ofensivo aos ditames do Estado Democrático de Direito e aos preceitos fundantes de nossa república (Preâmbulo da CF/1988). ${ }^{3}$ Para que a própria noção de justo, para que o sen-

2. Luiz Rodrigues Wambier et al. Breves comentários à nova sistemática processual civil - Emenda constitucional n. 45/2004 (Reforma Do judiciário), Leis 10.444/2002, 10.358/2001 e 10.352/2001. 3. ed. São Paulo: Ed. RT, 2005. p. 108.

3. "Nós, representantes do povo brasileiro, reunidos em Assembleia Nacional Constituinte para instituir um Estado Democrático, destinado a assegurar o exercício dos direitos sociais e individuais, a liberdade, a segurança, o bem-estar, o desenvolvimento, a igualdade e a justiça como valores supremos de uma sociedade fraterna, pluralista e sem 
timento de justiça possam se concretizar, imperiosa se apresenta a ideia de autoridade e de respeito a esta autoridade.

Logo, não poderíamos pensar em justiça, ou melhor, pensar em realizá-la concretamente por meio do Poder Judiciário, sem pensarmos em celeridade, segurança e previsibilidade.

\section{CONSIDERAÇÕES INICIAIS}

Breve escorço histórico: a origem da palavra súmula remonta ao século XV e trazia a noção inicial de soma, pequena soma (summa, ae [summus] substantivo feminino); traduzindo, também, a ideia de resumo, sumário. Summa também encerrava a ideia de "o ponto mais alto; o primeiro lugar; a primeira categoria"; "a parte mais importante; ponto capital; ponto essencial"; "mando, supremo poder; autoridade suprema"; "chefe; cabeça"; eminente (p. ex. summa rerum $=$ o supremo mando).$^{4}$ Este mesmo sentido de "ponto mais alto; o primeiro lugar; a primeira categoria" também encontramos no Dicionário Latino-Português de Ernesto Faria, ${ }^{5}$ que traz até mesmo como sentido figurado da palavra summa, a ideia de "a parte mais importante, ponto culminante, apogeu, parte essencial (Quint. 3, 2, 1)"; "Supremo poder, mando, autoridade suprema (Cés. B. Gal. 2, 23, 4)".

O substantivo summa dará origem às palavras "sumário" e "súmula" e ao advérbio "sumariamente". No século XVII começa a se desenhar a feição da palavra como a conhecemos hoje: súmula (substantivo feminino) no sentido de breve resumo, vindo do latim summula - ae (cuja raiz é a summa). ${ }^{6}$ O Houaiss, inclusive, traz a seguinte definição para a palavra: "súmula. s.f. (1666 cf. Agiólogo) pequena suma; breve epítome ou resumo; sinopse, condensação. Etim lat. summula, ae' pequena soma, quantia". ${ }^{7}$ É a síntese, enfim.

preconceitos, fundada na harmonia social e comprometida, na ordem interna e internacional, com a solução pacífica das controvérsias, promulgamos, sob a proteção de Deus, a seguinte Constituição da República Federativa do Brasil" (destacamos).

4. Conferir a este respeito Torrinha, Francisco. Dicionário latino-português. 3. ed. Porto: Maranus, 1945. p. 840-841.

5. FARIA, Ernesto. Dicionário escolar latino-português. 2. ed. Rio de Janeiro: Ministério da Educação e Cultura - Companhia Nacional de Material de Ensino, 1956. p. 932.

6. Ver Antônio Geraldo da Cunha. Dicionário etimológico nova fronteira da língua portuguesa. 2. ed. 9. reimp. Rio de Janeiro: Nova Fronteira, 1997. p. 734-743.

7. HouAss, Antônio. Dicionário Houaiss da língua portuguesa. Rio de Janeiro: Objetiva, 2001. p. 2638. 
Logo, podemos perceber que a própria etimologia da palavra súmula encerra, também, a ideia de autoridade, de eminente, de "mando, supremo poder; autoridade suprema". Deste modo, percebemos que súmula traduz não apenas a ideia de um "breve resumo; condensação" (embora efetivamente traga em si mesma também essa ideia), mas traduz, outrossim, a ideia, muitas vezes pouco lembrada, de autoridade, de ordem, de mando, de supremo e eminente. Assim, não é apenas uma condensação. Poderíamos dizer que é uma condensação com a ideia de autoridade, resumo supremo. Desta feita, que ela vincule advém de sua própria autoridade.

A ideia de "sumular", em nosso ordenamento jurídico pós fundação da República, foi fruto da concepção do então Ministro do STF, Victor Nunes Leal, de que nos dá importante testemunho Evandro Lins e Silva (que, quando redigiu seu artigo, era o último Ministro daquela turma de 1963 do STF ainda vivo).

Deste modo, nos idos de 1963, com o intuito de traçar pequenos enunciados para temas a respeito dos quais o STF já havia se posicionado de modo reiterado, o Min. Victor Nunes Leal introduziu no nosso ordenamento a figura da súmula. Ela servia para dar publicidade aos entendimentos daquela Corte, bem como facilitar o trabalho de seus Ministros em questões já repetidas. Mas ainda não era vinculante, e mesmo assim já fora, na época, alvo de críticas e resistências. ${ }^{8}$

De lá para cá, foram aprovados 370 enunciados em sua 1. a sessão, datada de 13.12.1962, que após a Emenda Regimental de 1963 passaram a ser denominadas de súmulas. Posteriormente foram sendo aprovadas novas súmulas até chegarmos a de número 621, no ano de 1984. Houve, então, um vácuo de quase 20 anos sem novas súmulas, até que em 24.09.2003 o plenário do STF aprova, de uma só vez, 100 novas súmulas, totalizando 721 súmulas. Após esta aprovação em lote, outras súmulas foram gradativamente aprovadas, até completarmos o número atual de 736 súmulas, sendo a última aprovada em sessão do dia 26.11.2003. ${ }^{9}$

Com a edição da emenda constitucional que implementou a súmula com eficácia vinculativa, obrigatória, o Supremo editou as primeiras 13 súmulas vinculantes do país.

8. Cfr. Evandro Lins e Silva. Crise de hermenêutica e súmula vinculante. Disponível em: [http://campus.fortunecity.com/clemson/493/jus/m05-011.htm]. Acesso em: 16.09.2006. O autor era a favor das súmulas, mas sem efeito vinculativo.

9. Conferir a este respeito Mancuso, Rodolfo de Camargo, op. cit., p. 690. 


\section{O PROBLEMA DA MOROSIDADE DA JUSTIÇA}

Como advertia, há muito, Ruy Barbosa: "justiça atrasada não é justiça, senão injustiça qualificada e manifesta". ${ }^{10}$ Diante da tardança, não se pode falar mais em Justiça. Se ela era possível em um determinado caso concreto, a morosidade fez com que ela, Justiça, desaparecesse, açoitada pelo tempo. Temos, agora, apenas a injustiça; e não qualquer injustiça, mas aquela injustiça qualificada e manifesta de que nos fala Ruy Barbosa.

Qualificada e manifesta, posto que negou à parte a Justiça que lhe cabia em tempo hábil, torturando-a cruelmente com a insegurança e aflição do tempo que se esvai. Injustiça qualificada e manifesta é o que podemos ofertar aos cidadãos enquanto tivermos um Poder Judiciário moroso. ${ }^{11}$

É, pois, premente uma celeridade processual, sem a qual o Judiciário deixará de lado sua função pacificadora de conflitos para se tornar um órgão fomentador de angústias.

Nesse sentido, escrevem Mauro Cappelletti et al que:

"A Convenção Europeia para Proteção dos Direitos Humanos e Liberdades Fundamentais reconhece explicitamente, no art. $6 .^{\circ}, \S 1 .^{\circ}$, que a Justiça que não cumpre suas funções dentro de 'um prazo razoável' é, para muitas pessoas, uma justiça inacessível." 12

Mais do que uma Justiça inacessível, a Justiça que tarda é uma injustiça flagrante! Enquanto determinada situação levada ao Judiciário permanece indefinida, ela persiste fomentando a angústia das partes. É imperioso que as lides levadas ao Judiciário se resolvam e se estabilizem em prazo razoável, sem o qual a própria confiança da população neste que é um dos três poderes, das três pilastras do Estado Democrático de Direito, se esvai, falecendo junto com a Justiça.

Atento a isto, a mesma emenda constitucional que instituiu a eficácia vinculante às súmulas acrescentou como direito e garantia fundamental do cida-

10. Ruy Barbosa. Oração aos moços. 3. ed. Rio de Janeiro: Organização Simões, 1949. p. 59.

11. Como pontuam Cintra, Antônio Carlos de Araújo; Grinover, Ada Pallegrini; DinaMARCo, Cândido Rangel. Teoria geral do processo. 15. ed. São Paulo: Malheiros, 1999. p. 26: "Pois tudo toma tempo e o tempo é inimigo da efetividade da função pacificadora. A permanência de situações indefinidas constitui, como já foi dito, fator de angústia e infelicidade pessoal".

12. Cappelletti, Mauro; Bryant, Garth. Acesso à Justiça. 1. ed. reimp. Trad. Min. Ellen Gracie Northfleet. Porto Alegre: Fabris, 2002. p. 20. 
dão o direito a uma duração razoável do processo, acrescentando ao art. $5 .^{\circ}$ da CF/1988 a redação do seguinte inciso: "LXXVIII - a todos, no âmbito judicial e administrativo, são assegurados a razoável duração do processo e os meios que garantam a celeridade da sua tramitação".

A propósito, este ideal de um processo célere como um direito fundamental do cidadão remonta à Magna Charta, ${ }^{13}$ que, em 1215, já preconizava em seu art. 40: "O direito de qualquer pessoa a obter justiça não será por nós vendido, recusado ou postergado". ${ }^{14}$ Tantos séculos se passaram e ainda não conseguimos concretizar este ideal de uma Justiça célere!

E posto que o Estado avocou para si o poder de dizer o direito, a jurisdição, torna-se ele responsável e devedor para com o cidadão de dizê-lo em tempo hábil, em tempo razoável. Se o Estado chamou para si este poder, monopolizando-o em sua esfera, deve, pois, assumir os ônus decorrentes desta assunção, não podendo negar nem postergar a Justiça a nenhum cidadão.

E, embora não seja o único, a súmula vinculante é efetivamente um instrumento a mais para possibilitar a concretização desta utopia tão necessária que é uma Justiça mais célere, acabando com aquela situação que alguns denominam de "mora judicialmente legalizada". É claro que não é o único, mas certamente contribuirá - como de fato já o vem, conforme demonstram os dados estatísticos - positivamente.

Concordamos, sem dúvida, com aqueles que advogam que uma mudança de mentalidade na magistratura contribuiria e muito para desafogar o Judiciário. ${ }^{15}$ Bem como, concordamos ainda, com aqueles que advogam a necessidade, mais do que premente, de uma reforma processual que diminua e simplifique os recursos permitidos e contemplados em nosso ordenamento. ${ }^{16}$

13. Em sua redação original, vinha com o "h", que perdeu depois, passando a ser conhecida como Magna Carta. E ela também era redigida em latim e sem a separação em artigos, que costuma ser feita nas traduções para facilitar o estudo e a leitura. Ver Comparato, Fábio Konder. A afirmação histórica dos direitos humanos. 2. ed. São Paulo: Saraiva, 2001. p. 67-82.

14. No original inglês: "To no one will we sell, to no one will we refuse or delay, right or justice".

15. Neste sentido, conferir NAlini, José Renato. O Brasil precisa de súmula vinculante? Disponível em: [www.tj.ro.gov.br/emeron/sapem/2002/julho/1907/ARTIGOS/A01. htm]. Acesso em: 16.09.2006.

16. A esse respeito, Rodolfo de Camargo Mancuso nos traz uma curiosidade alarmante do nosso sistema processual, relatada por Vicente Greco Filho, acerca do julgamento de um recurso de "embargos de declaração em agravo regimental de despacho de inde- 
Contudo, a despeito desses argumentos, há, indiscutivelmente, uma necessidade concreta que se nos apresenta de impor a criação de mecanismos já para desafogar o Judiciário, e a súmula vinculante é, efetivamente, um desses mecanismos.

Em entrevista ao Jornal do Commercio, a Min. Ellen Gracie Northfleet, quando na Presidência do STF, deu os alarmantes números: "distribuo 500 processos por dia. Até o fim do ano serão 20 mil novas ações". Ora, é inconcebível em qualquer país que a mais alta Corte Constitucional julgue 20 mil novas ações por ano, o que a impede de dedicar-se às grandes causas, de grande impacto de massas, de repercussão geral. ${ }^{17}$

Neste contexto, como nos noticiam o Min. Gilmar Mendes e Samantha Meyer, ${ }^{18} \mathrm{em} 1963$ (ano em que o Min. Vitor Nunes Leal instituiu a figura das súmulas) o STF tinha recebido 8.126 processos, contra os 160.453 do ano de 2002 (houve um decréscimo para 83.667 em 2004); ninguém pode ficar indiferente a estes números! Ou seja, a realidade numérica torna imperiosa a adoção de medidas para tornar a nossa Suprema Corte mais efetiva e racionalizar o discurso jurídico. Como bem o disse o Chief Justice Vinson: ${ }^{19}$

"Para permanecer efetiva, a Suprema Corte deve continuar a decidir apenas os casos que contenham questões cuja resolução haverá de ter importância imediata para além das situações particulares e das partes envolvidas ('To remain effective, the Supreme Court must continue to decide only those cases which present questions whose resolutions will have immediate importance far beyond the particular facts and parties involved')".

Desta feita, sob o prisma da celeridade processual, conveniente se faz a adoção da súmula vinculante, conquanto haja a necessidade de implementação de outras medidas eficazes para que a nossa Justiça se torne, enfim, célere.

ferimento de embargos de divergência em agravo de despacho denegatório de recurso extraordinário" (Mancuso, Rodolfo de Camargo, op. cit., p. 691).

17. Neste sentido, Arruda Alvim nos dá conta, também, dos números alarmantes do STJ, que julgava, em 2000, cerca de 120 mil processos por ano (Arruda Alvim Netto, José Manoel de. A EC n. 45 e o instituto da repercussão geral. In: Arruda Alvim Wambier, Teresa et al (coords.). Reforma do Judiciário - Primeiras reflexões sobre a Emenda Constitucional n. 45/2004. São Paulo: Ed. RT, 2005. Cap. VII, p. 67).

18. Gilmar Mendes e Samantha Meyer Pjlug. Passado e futuro da súmula vinculante: considerações à luz da Emenda Constitucional n. 45/2004. In: Renault, Sérgio Rabello Tamm; Bottini, Pierpaolo. Reforma do Judiciário - Comentários à Emenda Constitucional n. 45/2004. São Paulo: Saraiva, 2005. p. 331-332.

19. Apud Mendes, Gilmar; PJlug, Samantha Meyer, op. cit., p. 374-375. 
Lembremos, ainda, que a súmula vinculante poderá servir de juízo de admissibilidade, autorizando o juiz a não receber apelação em conformidade com entendimento sumulado. ${ }^{20}$

\section{0 PROBLEMA DA SEGURANÇA JURÍDICA E DA PREVISIBILIDADE DAS DECISÕES JUDICIAIS}

Contudo, em nosso sentir, embora tenhamos iniciado nossos argumentos pelo problema da celeridade processual, é justamente o problema da segurança jurídica, bem como da previsibilidade das decisões judiciais, ${ }^{21}$ aliada à necessidade de respeito à autoridade, que de fato tornam necessária a adoção da súmula vinculante.

Esta súmula por si só não resolverá o problema da celeridade. Bem como outras medidas podem ser, quiçá, mais eficazes (simplificar e reduzir o número de recursos, por exemplo).

Porém, ela é extremamente necessária para resgatarmos a própria ideia de uma Corte Superior e dar à sociedade um sentimento de segurança e confiabilidade, bem como que cada cidadão possa esperar algo de suas contendas, posto que haveria no ordenamento uma certa previsibilidade [racionalidade do discurso jurídico] das decisões, não ficando ele refém daquilo que alguns doutrinadores, com muita propriedade, denominaram "loteria jurídica".

Tal situação compromete a própria credibilidade das instituições que integram o Poder Judiciário, institucionalizando um caos "lotérico" de decisões, sem que nenhum cidadão saiba o que efetivamente esperar da Justiça.

A súmula vinculante funciona, assim, como instrumento de racionalização do discurso jurídico. Em tempos de amplo acesso à informação (com a popularização da Internet e com a maior informatização do Judiciário, bem como com

20. Conferir Nelson Nery Junior e Rosa Maria de Andrade Nery. Código de Processo Civil comentado e legislação extravagante. 10. ed. São Paulo: Ed. RT, 2007. p. 862-866. Sendo que o STF firmou entendimento de que as súmulas vinculantes são impeditivos de recursos, incluindo-se também, portanto, os recursos extraordinários e agravos de instrumento.

21. A este respeito, conferir Nelson Nery Junior. Boa-fé objetiva e segurança jurídica. Eficácia da decisão judicial que altera jurisprudência anterior do mesmo tribunal superior. In: Ferraz Junior, Tercio Sampaio; Carrazza, Roque Antonio; Nery Junior, Nelson. Efeito "ex nunc" e as decisões do STJ. Barueri: Manole, 2008. Especialmente p. 82-91. 
a transmissão de julgamentos do STF), mais ainda se impõe a racionalização do discurso jurídico.

E uma das funções dos Tribunais Superiores é justamente "uniformizar o entendimento da Constituição Federal (STF) e da lei federal no país (STJ e TST), toda decisão tomada pelas Cortes Superiores em casos individuais projetam o entendimento no tribunal, atuando como que paradigma para casos futuros e idênticos". ${ }^{22}$ Assim, as decisões dos Tribunais Superiores funcionam, pois, como "fator de implementação da paz social e como paradigmas jurisprudenciais ou decisões-quadro". ${ }^{23}$

Neste diapasão, essas decisões paradigmáticas proferidas pelos Tribunais Superiores contribuem, justamente, para que o discurso jurídico se dê de forma mais racional, conferindo, pois, maior segurança jurídica aos jurisdicionados, que têm como saber o quê esperar do Judiciário (previsibilidade).

É preciso, portanto, compreender essa segurança jurídica como um valor mesmo, necessário à vida em sociedade e que precisa ser respeitado.

Poderíamos afirmar ser a segurança jurídica "elemento de existência do Estado Democrático de Direito", ${ }^{24}$ em especial ante os dizeres do Preâmbulo da $\mathrm{CF} / 1988^{25}$ e $1 .^{\circ}$, de tal sorte que violentar a segurança jurídica significaria "negar o próprio Estado Democrático de direito, fundamento da República brasileira". ${ }^{26}$

22. Idem, p. 78.

23. Idem, p. 78-79.

24. Cfr. Nelson Nery Junior. Teoria geral dos recursos. 6. ed. São Paulo: Ed. RT, 2004. Item 3.8 , p. 500, 501, 506, e, em especial, p. 510 e 511 (embora o autor faça mais referência à coisa julgada).

25. Nesse sentido: "O preâmbulo afirma princípios constitucionais e por essa razão expressa uma espécie de manifestação declaratória a respeito de circunstâncias históricas, políticas e constitucionais (Sachs-Huber. KommGG ${ }^{3}$, coment. 11 ao preâmbulo da GG, p. 24). Por isso é importante o papel desempenhado pelo preâmbulo na interpretação de outros princípios e preceitos constitucionais (Von Münch-Kunig-Kunig. GGK5 ${ }^{5}$, coment. 11 ao preâmbulo da GG, p. 5; Sachs-Huber. KommentGG ${ }^{3}$, coment. 11 a ao preâmbulo da GG; BVerfGE 63, 343 [370]). Por isso as cláusulas do preâmbulo têm natureza prescritiva. A Corte Constitucional Federal da Alemanha afirmou que o preâmbulo da Constituição tem não apenas caráter político (BVerfGE 5, 85 [127]), mas também possui caráter jurídico (BVerfGE 36, 1 [17])" (Cfr. Nery Junior, Nelson; Nery, Rosa Maria de Andrade. Constituição Federal comentada e legislação constitucional. 2. ed. São Paulo: Ed. RT, 2009. Comentários 5 e 6 ao Preâmbulo da Constituição Federal).

26. Nelson Nery Junior. Teoria geral... cit., item 3.8, p. 501. 
A esse respeito, pontua Humberto Theodoro Júnior que:

"É essa tempestade de ventos e torrentes em entrechoque nas reformas constantes e profundas por que passa o direito positivo de nossos dias que nos convidam a meditar e ponderar sobre um princípio, um valor, um fundamento, do qual não se pode prescindir quando se intenta compreender a função primária da normatização jurídica. Trata-se da segurança jurídica, que nosso legislador constituinte originário colocou com uma das metas a ser atingida pelo Estado Democrático de Direito, ao lado de outros valores igualmente relevantes, como a liberdade, o bem-estar, a igualdade e a justiça, todos eles guindados à categoria de 'valores supremos de uma sociedade fraterna, pluralista e sem preconceitos, fundada na harmonia social' (Preâmbulo da Constituição de 1988)"27 (destacamos).

E isso é verdadeiro em nosso ordenamento jurídico posto que a segurança jurídica é um valor intrínseco, necessário e almejado em nossa Carta Magna, como um verdadeiro princípio basilar para a mantença da própria sociedade. Não se concebe um Estado Democrático de Direito sem que haja segurança jurídica (Preâmbulo e art. 1. ${ }^{\circ}$ da CF/1988).

É preciso que cada cidadão saiba, com precisão e clareza, o que pode e o que não pode fazer, podendo confiar na segurança jurídica dos precedentes, até como proteção à sua boa-fé objetiva. ${ }^{28-29}$ É preciso haver proteção à boa-fé objetiva do cidadão que age confiando nas decisões reiteradas dos Tribunais Superiores. Daí podermos afirmar que se é preciso haver transparência e estabilidade nas leis, também é preciso haver transparência e estabilidade na interpretação dada a essas leis.

Se há instabilidade na interpretação, se ela é reduzida a uma verdadeira "loteria jurídica", ficam os cidadãos relegados ao incognoscível, ao caos, sem

27. Humberto Theodoro Júnior. A onda reformista do direito positivo e suas implicações com o princípio da segurança pública. RePro 136/32-57.

28. Nelson Nery Junior. Boa-fé objetiva... cit., p. 82-90.

29. Nesse sentido, determina a Constituição Federal Suíça, art. 9. ${ }^{\circ}$, que: "Cada pessoa tem o direito de exigir dos órgãos estatais tratamento sem arbitrariedade e segundo a boa-fé" (apud Nelson Nery Junior. Boa-fé objetiva... cit., p. 86) ["Art. 9. Protection contre l'arbitraire et protection de la bonne foi. Toute personne a le droit d'être traitée par les organes de l'Etat sans arbitraire et conformément aux règles de la bonne foi"]. No nosso ordenamento jurídico, a boa-fé aplicada à Administração Pública (na qual também se insere, por óbvio, o Poder Judiciário) encontra-se positivada, especialmente, não art. 37, caput, da CF/1988, e, ainda, no art. 5. ${ }^{\circ}$, LXXIII, da CF/1988 e no art. 2. ${ }^{\circ}$, parágrafo único, IV, da Lei 9.784/1999. 
saber, ou ao menos sem ter certeza, se a sua conduta é permitida ou não, o que se transforma em um fator de instabilidade social, que enfraquece o próprio Estado e a sociedade.

A segurança jurídica é, de fato, um valor e, mais do que isso, é um valor que permite até mesmo a concretização dos demais valores constitucionais. Como realizarmos a concretização de outros valores jurídicos em uma sociedade instável, sem segurança jurídica?

Neste sentido, assim pontua Nelson Nery Junior (acerca da importância da segurança jurídica):

"Referimo-nos à boa-fé como manifestação clara dos princípios do Estado Democrático de Direito (art. 1. ${ }^{\circ}$, caput, da CF/1988), da segurança jurídica (art. 1. ${ }^{\circ}$, caput, e art. $5^{\circ}$, caput, ['(...) direito à vida, à liberdade, à segurança e à propriedade (...)'] e art. 5. ${ }^{\circ}, \mathrm{XXXVI}$, da CF/1988 [irretroatividade]), da legalidade e da moralidade administrativa (art. 37, caput, da CF/1988) que, interpretados sistemática e finalisticamente, implicam a conclusão de que é direito fundamental de todos exigir que os poderes públicos, por meio de todos os órgãos dos Poderes Executivo, Legislativo e Judiciário, em suas funções típicas e atípicas, ajam de conformidade com a segurança jurídica, da qual a boa-fé objetiva é instrumento de atuação.Trata-se, portanto, de direito fundamental previsto na Constituição brasileira." ${ }^{30}$

Deste modo, podemos observar, a toda evidência, tratar-se a segurança jurídica em um valor mesmo, com trato de direito fundamental, protegido pela Constituição Federal. E a súmula vinculante traz em seu bojo justamente a perspectiva de uma maior segurança jurídica na aplicação do direito.

Como advertia Theóphilo Cavalcanti Filho, a respeito da segurança jurídica:

"O homem (...) para poder conviver com os demais, necessita de saber não só o que pode fazer, mas também o que esperar que os outros façam. E também precisa ter certeza de que os demais, se não agirem da maneira como devem, serão compelidos a proceder da maneira adequada. De um lado, impõe-se a certeza, quanto à ação que deve ser realizada, e por outro, a segurança quanto a que, necessariamente, as coisas se darão da maneira como devem ser. Se a situação fosse diferente, logo descambaríamos para o caos. Não haveria certeza em relação a nada. E uma sensação de absoluta intranquilidade se apossaria de todos. A convivência se transformaria em um verdadeiro martírio." ${ }^{31}$

30. Nelson Nery Junior. Boa-fé objetiva... cit., p. 87.

31. Apud Rodolfo de Camargo Mancuso, op. cit., p. 702. 
Logo, não podemos apostar em que seja possível uma convivência harmônica em sociedade em meio a um caos jurídico, em meio a uma "loteria jurídica".

É imperioso, pois, que haja previsibilidade e segurança jurídica nas decisões judiciais, como um direito fundamental do cidadão (Preâmbulo e art. $1 .^{\circ}$ da CF/1988). Disso decorre a busca por uma racionalização do discurso jurídico. ${ }^{32}$

Portanto, é fundamental haver preocupação em encontrar um certo padrão de racionalidade que torne o discurso jurídico, ou melhor, no presente estudo, as decisões judiciais harmônicas, com um certo grau de previsibilidade e segurança jurídica, que permitam ao cidadão saber o que pode ou não fazer.

Desta feita, nesta busca por um discurso jurídico racional, o Judiciário, antes de ser um Poder que não sofre ou encontra qualquer limitação, como se tal poder fosse atribuído ilimitadamente ao magistrado, é, ao revés, limitado por um certo padrão de racionalidade. É, antes de mais nada, um dever do magistrado e um direito fundamental do cidadão que este mesmo discurso jurídico se apresente de forma racional, previsível, traduzindo-lhe em segurança jurídica. Podemos lembrar, inclusive (para corroborar nosso pensamento), a polêmica suscitada pelas decisões proferidas no caso Richarlysson e no caso que negou aplicação à Lei Maria da Penha (ou, ainda, e também sob o prisma do respeito à autoridade, lembrar as decisões polêmicas e em clara afronta ao STF, como as ocorridas no caso Daniel Dantas, proferidas pelo Juiz De Sanctis). Ora, qual o porquê da polêmica, caso o discurso jurídico não conhecesse qualquer limitação ou não comungasse de algum padrão de racionalidade? É justamente porque o discurso jurídico experimenta limitações que tais decisões causaram tanta polêmica, porque destoaram radicalmente do padrão de racionalidade

32. Conferir a esse respeito Tercio Sampaio Ferraz Junior e Juliano Souza de Albuquerque Maranhão. Função pragmática da justiça na hermenêutica jurídica: lógica "do" ou "no" direito? Revista do Instituto de Hermenêutica Jurídica - A filosofia "no" direito e a filosofia "do" direito. n. 5, vol. I, p. 273-318; e Juliano Souza de Albuquerque Maranhão. Some operators for refinement of normative systems. In: VerHEIJ, Bart; Lodder, Arno R.; Loui, Ronald P.; Muntjewerff, Antoinette J. (eds.). Legal knowledge and information systems, frontiers in artificial intelligence and applications. Amsterdam: IOS Press, 2001. p. 103-115. E, em especial: "Assim, a resposta sobre uma ação particular para um caso, com determinada propriedade, deve ser coerente com a solução encontrada para aquela mesma ação na hipótese de ausência daquela propriedade, ou ainda, coerente com a solução encontrada para outras ações análogas ou relacionadas com aquela primeira ação considerada. Isso leva o intérprete doutrinário a uma reconstrução de um sistema normativo com soluções coerentes para casos hipotéticos relevantes" (Tercio Sampaio Ferraz Junior e Juliano Souza de Albuquerque Maranhão, op. cit., p. 284). 
comumente aceito em sociedade. O juiz não seria, portanto, completamente livre; "o juiz não escolhe entre muitas possíveis decisões, senão que encontra dentro da moldura da lei, a única decisão correta". ${ }^{33}$

Deste modo, ao juiz não é dado um poder supremo e ilimitado de decidir sem qualquer parâmetro mínimo em seu discurso jurídico; ao revés, deve, por óbvio, decidir conforme seu livre convencimento, mas dentro e a partir do ordenamento jurídico, o que implica dizer dentro e a partir do padrão de racionalidade que é dado ao discurso jurídico.

Ademais, tais situações contribuem para o caos decorrente da insegurança jurídica que elas trazem, deixando o cidadão sem saber se sua conduta é juridicamente permitida ou não, sem saber o que esperar do Judiciário.

Esse é, inclusive, um dos problemas com a súmula impeditiva de recurso, que não impede que haja diversos julgamentos dissonantes ao entendimento do STJ, apenas vedam seguimento ao recurso cuja questão já esteja de acordo com o entendimento sumulado. Nos dizeres de Arruda Alvim:

"A súmula que se encontra no âmbito do processo de emenda constitucional, em relação ao STJ, terá eficácia menor do que aquela instituída para o STF, pois esta produz efeitos vinculantes erga omnes, ao passo que a sugerida para o STJ, apenas, impedirá recursos que a contrariem. De certa forma, se aprovada, ter-se-á uma eficácia menos direta, afetando diretamente apenas os que recorram por meio de recurso especial, contrapostamente ao que foi sumulado, ao passo que a do STF tem eficácia direta." ${ }^{34}$

É importante, ao menos no caso do STF (como Corte Constitucional), que a súmula tenha efeito vinculante, direto e erga omnes, a não permitir que a "loteria jurídica" se instaure, assegurando um certo padrão de previsibilidade e segurança jurídica às decisões judiciais, contribuindo, pois, para a racionalização do discurso jurídico.

\section{A NECESSIDADE DO RESPEITO À AUTORIDADE}

A esse respeito, há muito já constatava Hannah Arendt, ao dissertar sobre o que é a autoridade:

"Para evitar mal-entendidos, teria sido muito mais prudente indagar no título: o que foi - e não o que é - autoridade? Pois meu argumento é que somos

33. Cfr. José Manoel de Arruda Alvim Netto, op. cit., p. 70.

34. Idem, p. 66. 
tentados e autorizados a levantar essa questão por ter a autoridade desaparecido do mundo moderno. Uma vez que não mais podemos recorrer a experiências autênticas e incontestes comuns a todos, o próprio termo tornou-se enevoado por controvérsia e confusão."35

É tempo de resgatarmos a autoridade, o respeito à autoridade. O respeito à autoridade da Lei e do Judiciário (e com o resgate do respeito à autoridade do Judiciário, resgataremos também a confiança da população nele).

A insegurança jurídica trazida pela inconstância de decisões judiciais, que não respeitam a autoridade do STF, órgão máximo do Poder Judiciário, em entendimentos já sumulados, apenas contribuem para a própria realidade em que vivemos em nossa sociedade, de desrespeito à autoridade da Lei e das instituições de nosso país.

Em sendo os atos determinados pelas ideias e sentimentos, quanto maior for a consciência das verdades jurídicas fundamentais, maior será também a consciência não só da utilidade, mas da necessidade de elaborar bem as leis e de segui-las religiosamente, contribuindo para uma elevação de caráter. ${ }^{36}$

Isso se torna ainda mais relevante, atualmente, na chamada era da informação, com o acesso virtual às decisões proferidas; cada vez mais a população tem se aproximado do Judiciário e cada vez mais tem constatado um desrespeito à autoridade.

Esse desrespeito era facilmente percebido, por exemplo, no emblemático caso dos Bingos. Embora já houvesse um posicionamento consolidado do STF a esse respeito, pululavam liminares autorizando o funcionamento dos Bingos, o que diuturnamente era noticiado pela mídia. ${ }^{37}$

Tal situação apenas levava o homem comum a não ter certeza do que fazer ou esperar das decisões judiciais. Afinal, se nem o pensamento consolidado da mais alta Corte era respeitado, o que eles deviam respeitar? Um verdadeiro caos que só foi solucionado com a edição de uma súmula vinculante do STF ${ }^{38}$

Logo, isto serve para ilustrar que a própria noção de autoridade e de respeito a essa autoridade são extremamente necessários para a convivência em

35. Hannah Arendt. Entre o passado e o futuro. 6. ed. São Paulo: Perspectiva, 2007. p. 127.

36. Cfr. Pedro Lessa. Estudos de filosofia do direito. 2. ed. Campinas: Bookseller, 2002. p. 12.

37. Insegurança jurídica que somente foi solucionada com a edição da Súmula Vinculante 2 .

38. Podemos lembrar, ainda, como já citado anteriormente, o conflito havido entre STF e o juiz De Sanctis no caso Daniel Dantas, amplamente noticiado pela mídia. 
democracia, especialmente com a massificação do acesso à informação promovido pela Internet.

Desta feita, como já deixamos consignar anteriormente, não houve, com o advento da súmula vinculante, uma afronta à liberdade de julgar do magistrado. Ao revés, esta liberdade lhe foi mantida, como nem poderia deixar de sê-lo, mas isto não quer dizer que o intérprete (magistrado) goze de poderes ilimitados. Não trocamos a tirania da lei na escola da exegese pela tirania do intérprete. Ao juiz não são concedidos poderes de tiranos para que possa julgar como bem o entenda, sem respeito ao que quer que seja. Não goza o magistrado de poderes tais que, lembremos o caso dos Bingos, mesmo diante de um posicionamento consolidado do STF, possa continuar a dar liminares que prestavam o desserviço de desacreditar as instituições neste país, ao transmitir a ideia de que não se deve respeito às decisões da nossa Corte Máxima! Mais uma vez, o intérprete não pode trajar as vestes de um tirano; o Juiz não pode pretender ser o Estado (L'État c'est moi)!

Neste sentido, pontua Sérgio Seiji Shimura que:

"O alcance e a interpretação da lei não podem ficar ao talante pessoal dos seus aplicadores. Se o juízo não é um órgão cego e automático de aplicação das leis, tampouco pode ser o senhor absoluto do direito, nem contribuir para com o aumento da litigiosidade ao conferir tratamento desigual a situações idênticas. Trata-se, portanto, de sopesar valores: a liberdade de interpretação da lei não pode se sobrepor ao entendimento sumulado, produto de reiteradas decisões, da mais alta Corte do país." 39

O STF é a instituição guardiã da nossa Carta Magna; os ataques recentemente dirigidos à nossa mais alta Corte prestam um verdadeiro desserviço ao país ao tentar desestabilizar uma das sólidas pilastras do Estado Democrático de Direito, transmitindo essa ideia à nação (ao não se dar cumprimento a ordens do STF, ao se grampear o seu Presidente, o Min. Gilmar Mendes). O STF é o responsável pela estabilização entre os Poderes.

Como consigna Ives Gandra da Silva Martins que "A Constituição, que rege os destinos do Estado Democrático de Direito, portanto, sedia no pretório excelso seu elemento de estabilização"40 (destacamos). Em igual sentir, Senador José Sarney, para quem:

39. Sérgio Seiji Shimura. Súmula vinculante. In: Arruda Alvim Wambier, Teresa (coord.). et al. Reforma do Judiciário - Primeiras reflexões sobre a Emenda Constitucional $n$. 45/2004. São Paulo: Ed. RT, 2005. p. 762.

40. Ives Gandra da Silva Martins. O STF e a estabilidade das instituições. Folha de S. Paulo, Cad. Opinião, 16.09.2008. 
"Nada pior para o povo, para o Poder Executivo, Legislativo, a liberdade de imprensa, juízes, advogados e procuradores do que o Supremo ser alvo de ataques e contestações, o enfraquecimento de sua autoridade" e mais, lembra o autor o exemplo estadunidense "Veja-se o exemplo americano. Bush perdeu a penúltima eleição pelo voto popular e foi duvidosa sua vitória no colégio eleitoral. A Suprema Corte vem e diz: o Presidente é George Bush. Todos aceitaram, e o perdedor, Al Gore, acatou a decisão, afirmando que mais importante do que ser eleito era a integridade da Suprema Corte."41

Desta feita, o desrespeito à autoridade da nossa Suprema Corte que temos observado nos últimos tempos, presta um dos maiores desserviços à nação, que é desestabilizar um dos pilares do Estado Democrático de Direito, responsável justamente pela estabilização entre os poderes!

Como pontua Nelson Nery Junior:

"A jurisprudência, principalmente a dos Tribunais Superiores, traz aos jurisdicionados determinados vínculos, não por conta do efeito vinculante das súmulas do STF editadas com base no art. 103-A da CF/1988, mas pela autoridade dos tribunais e o respeito que todos thes devem"42 (destacamos).

Assim, mesmo quando não se trate de efeito vinculante de uma determinada súmula, o respeito à autoridade dos Tribunais Superiores se impõe.

\section{Matérias que podem Ser objeto de súmula Vinculante}

Em primeiro lugar, posto que a súmula vinculante foi criada apenas para o STF, não tendo contemplado também o STJ, pode-se afirmar, desde logo, que apenas questões que envolvam matéria constitucional podem ser objeto de súmula vinculante. Ou seja, não poderia haver uma súmula vinculante que verse apenas sobre matéria infraconstitucional.

Outro requisito necessário é que a questão objeto de discussão seja passível de ser sumulada, ou seja, que não se trate de questão necessariamente aberta e que, portanto, não poderia ser objeto de súmula.

Desta feita, os chamados conceitos vagos, por exemplo, jamais podem ser objeto de súmula vinculante. Certos campos no direito são necessariamente vagos, abertos (função social, boa-fé, devido processo legal etc.) e não podem ser definidos de forma fechada, o que contraria a própria ideia de sumular

41. José Sarney. O Supremo Tribunal Federal. Folha de S. Paulo, Cad. Opinião, 07.09.2008.

42. Nelson Nery Junior. Boa-fé objetiva... cit., p. 80. 
(aliás, permitir que os chamados conceitos vagos pudessem ser sumulados, além de inviável na prática, poderia, sim, evocar a ideia de engessamento, posto que são propositalmente vagos para serem preenchidos e construídos ao longo dos tempos).

Neste sentido, assim assevera Arruda Alvim:

"Há 'ideias' que, em si mesmas, dificilmente, comportam uma definição. Mais ainda, se definidas forem, seguramente - agora no campo da operatividade do direito - passam a deixar de ensejar, só por isso, o rendimento esperado de um determinado instituto jurídico que tenha sido traduzido por meio de conceito vago. Com os valores, que são ideias indefiníveis (aporias e, portanto, inverbalizáveis), o que ocorre é que devem ser indicados por conceitos vagos; não são nem devem ser propriamente conceituados, mas devem ser apenas referidos, pois é intensa a interação entre eles e a realidade paralela a que se reportam. Não há como fazer que fiquem adequadamente cristalizados num texto de lei, ou que sejam verbalizados de forma plena na lei posta. Isto sempre ocorreu. Para perceber a dificuldade (senão impossibilidade), conducente a resultado fatalmente frustrador, em definir, tanto bastará recordar que, nos Estados Unidos, até hoje, não se definiu - e deliberadamente não se pretendeu definir -, exaurientemente, o que seja e, muito menos, qual o efetivo alcance que tenha a expressão due process of law, conforme informa a literatura, em mais de uma oportunidade." ${ }^{43}$

Por isso, não poderemos ter uma súmula definindo um conceito vago ou uma cláusula aberta. Estes termos vagos ou abertos podem ser referidos em uma súmula, mas não definidos, posto que, em si mesmos, não comportam uma definição, mas, ao revés, devem ser decantados ao longo dos tempos e da história, em constante evolução e processo de decantação. ${ }^{44}$ Isto porque essa vagueza e essa imprecisão são opções intencionais do legislador (opção política), ao optar por um sistema aberto ou semiaberto. A própria razão de ser dos conceitos vagos ou cláusulas gerais é permitir um juízo mais integrativo e equitativo por parte do intérprete, amoldando-os às nuances do caso concreto. Sumulá-los, sim, significaria um retrocesso e uma contrariedade ao sistema, e, nesse preciso ponto, significaria sim, efetivamente, um indevido engessamento da jurisprudência.

Deste modo, impõe-se que a súmula vinculante tenha como objeto validade, interpretação e eficácia de norma que comporte determinação ou definição.

43. José Manoel de Arruda Alvim Netto, op. cit., p. 74.

44. Idem, ibidem. 
Pode haver, claro, súmula vinculante que se refira à cláusula aberta ou conceito vago, sem pretender defini-los, mas estendendo seus efeitos, como é o caso da Súmula Vinculante 3, que estendeu o contraditório e a ampla defesa (conceitos vagos e que decantam ao longo dos tempos) aos processos perante o Tribunal de Contas da União. Deste modo, se é impossível uma súmula que pretenda definir o due process of law, é perfeitamente viável, no entanto, uma súmula que pretenda, por exemplo, garantir todos os direitos decorrentes do due process of law aos processos administrativos.

Por fim, como se depreende do próprio texto legal, é preciso que diga respeito à matéria constitucional a respeito da qual já haja reiteradas decisões do STF e que diga respeito a uma controvérsia atual, que "acarrete grave insegurança jurídica e relevante multiplicação de processos sobre idêntica questão" (art. 2. ${ }^{\circ}$, caput e $\S 1 .^{\circ}$, da Lei 11.417/2006).

Ademais, é importante que a súmula seja redigida da forma mais clara possível. Não se pode ter uma súmula vinculante que gere dúvidas acerca da sua aplicação ou não. O intuito dela é aclarar a validade, interpretação e a eficácia de normas determinadas e não tornar ainda mais tormentosa sua aplicação. A súmula deve, pois, ser clara e nítida para que a sua compreensão se dê pela sociedade como um todo.

\section{A SÚMULA VINCULANTE ENGESSA A JURISPRUDÊNCIA?}

Uma das maiores críticas à súmula vinculante, se não a maior, é a de que ela engessaria a jurisprudência. Até que ponto isso é verdadeiro?

Como assevera Carlos Maximiliano:

"Chama-se jurisprudência, em geral, ao conjunto das soluções dadas pelos tribunais às questões de direito; relativamente a um caso particular, denomina-se jurisprudência a decisão constante e uniforme dos tribunais sobre determinado ponto de direito." 45

E essa jurisprudência ficaria cristalizada por conta da súmula vinculante? A resposta, mais uma vez, é negativa.

Isto seria verdadeiro se não fosse previsto forma de alteração (revisão) ou, até mesmo, cancelamento da súmula vinculante. Mas a própria Lei já o prevê.

O art. 3. ${ }^{\circ}$ da Lei 11.417/2006 (Lei da Súmula Vinculante) traz, inclusive, o rol dos legitimados a pleitear a revisão ou cancelamento da súmula vinculante.

45. Carlos Maximiliano. Hermenêutica e aplicação do direito. 9. ed. Rio de Janeiro: Forense, 1979. p. 176. 
É claro que a realidade é mais rica do que podem prever a lei e as súmulas. É verdadeiro, outrossim, que as sociedades evoluem; valores mudam, concepções se alteram. Igualmente é verdadeiro que pode haver substancial alteração dos Ministros que integram a nossa mais alta Corte, mudando, pois, seu entendimento acerca de um determinado assunto. É ínsito à hermenêutica e à aplicação do direito que estas sejam situadas no tempo, tendo caráter histórico-evolutivo. ${ }^{46}$

Por isso, é necessário que haja formas democráticas de alteração ou revogação da súmula vinculante editada, mas que não guarde mais correspondência com a realidade. E assim está previsto em lei.

Nela, a sociedade civil está devidamente representada quer pelo Presidente da República e Governadores; pela mesa dos Congressistas (art. 3. ${ }^{\circ}$, II, III, IX, da Lei 11.417/2006), quer ainda por Partidos Políticos com representação no Congresso Nacional e Confederação Sindical ou Entidade de Classe.

Os advogados também estão representados e podem pleitear revisão e cancelamento da súmula por meio do Conselho Federal da OAB. Assim também ocorre com a magistratura, que pode fazer o pleito por meio dos Tribunais Superiores e Tribunais de Justiça dos Estados (bem como entidade de classe). Ainda estão legitimados o Procurador-Geral da República e o Defensor Público-Geral da União.

Deste modo, há, sim, meios democráticos de alteração ou revisão de súmula vinculante que, por qualquer motivo, não guarde mais correspondência com a realidade.

Nesse sentido, conforme pontuam o Min. Gilmar Mendes e Samantha Meyer:

"A possibilidade de revisão ou cancelamento de súmula é de extrema relevância quando se tem em vista que é da natureza da própria sociedade e do direito estar em processo de evolução contínua. Nesse sentido, faz-se imprescindível a possibilidade de alteração das súmulas vinculantes, para que elas possam ser adequadas a essas necessidades, também de índole prática. Todavia, do mesmo modo que a adoção de uma súmula vinculante não ocorre de um momento para o outro, exigindo que a matéria tenha sido objeto de reiteradas decisões sobre o assunto, a sua alteração ou modificação também exige uma discussão cuidadosa. (...). Tal questão foi objeto de pronunciamento do

46. Nesse sentido, Gilmar Mendes e Samantha Meyer Pjlug, op. cit., p. 350, verbis: "a atividade hermenêutica nada mais é do que um procedimento historicamente situado" (destacamos). 
Min. Sepúlveda Pertence, em pronunciamento perante a Câmara dos Deputados: 'É muito mais fácil prestar atenção a um argumento novo, num mecanismo de revisão de súmula, do que num dos 5 ou 6 mil processos a respeito que subam num determinado ano ao STF, até porque a sentença que contém o argumento novo tem de ser sorteada, porque não dá para conferir mais do que por amostragem."'47

Logo, há meios democráticos para se pretender a revisão ou o cancelamento de uma determinada súmula vinculante, caso seu entendimento não guarde mais correspondência com a realidade, ou se mostre equivocado, ou, ainda, não reflita mais o entendimento da Corte Suprema.

Contudo, é preciso ater-se ao meio adequado para seu questionamento, não se admitindo tentativas de questionamento por via manifestamente incabível, como foram os casos dos habeas corpus arquivados pelos Ministros Joaquim Barbosa, Menezes Direito e Ellen Gracie, posto que pretendiam, por via não contemplada na norma e de forma equivocada, questionar a Súmula Vinculante 11 , que regulamenta o uso de algemas.

Desta feita, a súmula vinculante não é imutável, mas deve ser atacada pelos meios próprios, não sendo possível pretender modificá-la por meios outros como habeas corpus ou mandado de segurança, máxime diante do fato de que há instrumento hábil e expresso previsto em lei para sua revisão, modificação ou cancelamento.

Demais disso, como vimos anteriormente, somente pode ser objeto de súmula vinculante matérias que comportem determinação, definição. Logo, não significa que toda e qualquer matéria pode ser objeto de súmula vinculante, de sorte a pôr em risco a evolução da jurisprudência, engessando-a indevidamente.

Assim, não podem, por óbvio, ser objeto de súmula vinculante matéria que não comporte determinação ou definição peremptória, especialmente aquelas que conferem, justamente, mobilidade ao sistema, permitindo uma maior atuação discricionária (discricionariedade essa, contudo, realizada dentro e a partir do próprio ordenamento jurídico, preenchendo os campos discricionariedade à luz de todos os preceitos orgânicos do próprio sistema jurídico, ${ }^{48}$ não se consubstanciando, pois, em liberdade irrestrita e ilimitada dada ao intérprete, o que nos conduziria a um cenário de insegurança jurídica, permitindo abu-

47. Idem, p. 352.

48. Cfr. Karl Larenz. Metodologia da ciência do direito. 3. ed. Lisboa: Fundação Calouste Gulbenkian, 1997. p. 82-83. 
sos; deve, pois, o intérprete, nessas hipóteses, agir com hesitação cautelosa) ${ }^{49}$ do intérprete, como é o caso dos princípios gerais de direito, conceitos legais indeterminados (e os conceitos legais determinados pela função) e as cláusulas gerais. ${ }^{50}$

Logo, a súmula vinculante existe para resolver controvérsia atual acerca de matéria que comporte, consequentemente, determinação, podendo ser sumulada, não incorrendo, pois, no seu uso correto, no risco de engessar o sistema.

E, repita-se, caso o STF se haja com desacerto na edição de uma determinada súmula vinculante, ou ela não mais corresponda aos anseios da sociedade, a própria Lei da Súmula Vinculante já prevê os meios adequados para sua revisão ou até mesmo cancelamento.

\section{E EM CASO DE DESCUMPRIMENTO?}

De nada adiantaria um instituto de vanguarda, se não fosse dotado de efetividade. De nada adiantaria o STF sumular de forma vinculante seus entendimentos, se não fosse respeitado.

Decorre daí a relevância que se tem dotar o STF de instrumentos para fazer valer a súmula vinculante, evitando que a emenda constitucional não tenha efetividade.

Deste modo, caso não se dê cumprimento a uma súmula vinculante, ou que se lhe dê aplicação de forma indevida, caberá reclamação ao STF, que, julgando-a procedente, "anulará o ato administrativo ou cassará a decisão judicial impugnada, determinando que outra seja proferida com ou sem aplicação da súmula" (conferir arts. $7 .^{\circ}, 8 .^{\circ}$ e $9 .^{\circ}$ da Lei 11.417/2006).

Contudo, este é um ponto que merece melhor reflexão legislativa, sob pena de, em vez de a súmula vinculante ser uma solução para os problemas de celeridade, segurança e isonomia do STF, tornar-se, ao revés, uma avalanche de reclamações a abarrotá-lo, frustrando as expectativas geradas pela lei.

A esse respeito, assim pontuam o Min. Gilmar Mendes e Samantha Meyer:

"Daí talvez a necessidade de que a lei preveja procedimento administrativo adequadodemodoapermitir, tanto quantopossível, queasquestõeseventualmente

49. Franz Wieacker. História do direito privado. 3. ed. Lisboa: Fundação Calouste Gulbenkian, 2004. p. 591.

50. A esse respeito, conferir Nelson Nery Junior e Rosa Maria de Andrade Nery. Código Civil comentado. 6. ed. São Paulo: Ed. RT, 2008. p. 189-192. 
suscitadas possam ser resolvidas na própria esfera da Administração. Não parece abusivo, nesse contexto, que se admita reclamação sem que se envidem esforços para solução da controvérsia no âmbito administrativo. Aqui reside um dos pontos mais delicados e mais relevantes do novo sistema inaugurado pela EC 45/2004. É que não se pode substituir a crise numérica ocasionada pelo recurso extraordinário pela multiplicação de reclamações formulada diretamente contra a Administração perante o STF."51

Porém, até que sobrevenha alguma alteração legislativa, toda vez que estivermos diante de um descumprimento de súmula ou de aplicação de forma indevida, caberá à parte prejudicada reclamação (que, em nosso sentir, tem natureza jurídica de ação) ${ }^{52}$ direta ao STF.

Outro ponto polêmico e que merece melhor enfrentamento por parte do Legislativo são as sanções (civil, penal e administrativa) para o descumprimento ou aplicação de forma indevida de súmula vinculante. Não nos parece que aquele que insista em não dar cumprimento às súmulas vinculantes deva sofrer sanções que transbordem a esfera administrativa. Entrementes, tal tema ainda merecerá maior reflexão legislativa no decorrer da existência da súmula vinculante. ${ }^{53}$

\section{ConClusÃo}

Deste modo, neste estudo, procuramos demonstrar as razões pelas quais, em nosso sentir, o instituto da súmula vinculante se apresenta como necessário.

Especialmente nos tempos atuais, em que a própria autoridade do STF tem sido desrespeitada e questionada.

Mais ainda, ante o amplo acesso a informações, inclusive com a democratização das sessões do STF, que agora são transmitidas ao vivo e sem cortes, impõe-se, ainda mais, uma racionalização do discurso jurídico, sob pena de o cidadão não poder contar com a segurança jurídica, posto que não obstante

51. Gilmar Mendes e Samantha Meyer Pjlug, op. cit., p. 352.

52. Neste sentido, acompanhamos o entendimento de Leonardo Lins Morato. A reclamação e a sua finalidade para impor o respeito à súmula vinculante. In: Arruda Alvim WAmbier, Teresa et al (coords.). Reforma do Judiciário - Primeiras reflexões sobre a Emenda Constitucional n. 45/2004. São Paulo: Ed. RT, 2005. p. 394-397.

53. A esse respeito, conferir Sérgio Seiji Shimura, op. cit., p. 765-766. 
assista às decisões reiteradas da Corte Máxima, observa que tais decisões não vêm sendo cumpridas.

As súmulas vinculantes vêm demonstrando que podem, sim, tornar-se um hábil instrumento para auxiliar a resolver o problema da morosidade da Justiça.

Ademais, ajudará, ainda, a dar maior previsibilidade e segurança jurídica às decisões do STF, evitando, deste modo, a figura da chamada "loteria jurídica", que tanto fere o princípio da isonomia, ao tratar de forma diferente questões jurídicas senão idênticas extremamente parecidas.

Assim, ante o trinômio da celeridade, segurança e previsibilidade, impõe-se o respeito às decisões reiteradas do STF e a necessidade de vinculação de seus entendimentos sumulados (de forma vinculativa, claro), como forma de estabilização e segurança do sistema jurídico, racionalizando-o.

Foi a própria Constituição Democrática quem elegeu o STF como seu fiel guardião. Logo, não se apresenta aceitável o desrespeito a essa palavra final, cujo desrespeito importa, também, por via de consequência, desrespeito à própria Constituição Federal.

Obviamente, como vimos, nem todas as matérias poderão ser objeto de súmula vinculante, mas somente as normas de direito constitucional que comportem determinação, para aclarar validade, interpretação e eficácia desta referida norma que comporte determinação ou definição, após reiteradas decisões do STF e diga respeito a uma controvérsia atual e que acarrete grave insegurança jurídica e relevante multiplicação de processos sobre idêntica questão.

Por fim, procuramos demonstrar que as críticas de que a súmula vinculante engessa a jurisprudência não procedem, posto que a própria Lei da Súmula Vinculante prevê os mecanismos adequados pelos quais ela pode ser modificada ou, até mesmo, cancelada. Logo se a sociedade, o magistrado, o advogado ou os próprios ministros, por exemplo, entenderem que determinada súmula vinculante não reflete mais o entendimento do STF ou que ela não guarda mais correspondência com a realidade, podem, pelas vias adequadas, pleitear-lhe a revisão ou, mesmo, o cancelamento.

E, por derradeiro, caso haja descumprimento da referida súmula, caberá reclamação ao Supremo. Este talvez seja o ponto da Lei da Súmula Vinculante que mereça alterações, a fim de não tornar o instituto da reclamação mais problemático do que o volume atual de feitos que dão ingresso no STF, bem como necessita a Lei da Súmula Vinculante ser mais clara quanto às consequências decorrentes do descumprimento reiterado da súmula vinculante, a fim de conferir-lhe efetividade. 


\section{REFERÊNCIAS BIBLIOGRÁFICAS}

Arendt, Hannah. Entre o passado e o futuro. 6. ed. São Paulo: Perspectiva, 2007. Arruda Alvim Netto, José Manoel de. A EC n. 45 e o instituto da repercussão geral. In: Arruda Alvim Wambier, Teresa et al (coords.). Reforma do Judiciário - Primeiras reflexões sobre a Emenda Constitucional n. 45/2004. São Paulo: Ed. RT, 2005.

Arruda Alvim Wambier, Teresa (coord.) et al. Reforma do Judiciário - Primeiras reflexões sobre a Emenda Constitucional n. 45/2004. São Paulo: Ed. RT, 2005.

Barbosa, Ruy. Oração aos moços. 3. ed. Rio de Janeiro: Organização Simões, 1949.

Cappelletti, Mauro; Bryant, Garth. Acesso à Justiça. 1. ed. reimp. Trad. Min. Ellen Gracie Northfleet. Porto Alegre: Fabris, 2002.

Cintra, Antônio Carlos de Araújo; Grinover, Ada Pallegrini; Dinamarco, Cândido Rangel. Teoria geral do processo. 15. ed. São Paulo: Malheiros, 1999.

Comparato, Fábio Konder. A afirmação histórica dos direitos humanos. 2. ed. São Paulo: Saraiva, 2001.

Cunha, Antônio Geraldo da. Dicionário etimológico nova fronteira da língua portuguesa. 2. ed. 9. reimp. Rio de Janeiro: Nova Fronteira, 1997.

FARIA, Ernesto. Dicionário escolar latino-português. 2. ed. Rio de Janeiro: Ministério da Educação e Cultura - Companhia Nacional de Material de Ensino, 1956.

Ferraz Junior, Tercio Sampaio; Carrazza, Roque Antonio, Nery Junior, Nelson. Efeito "ex nunc" e as decisões do STJ. Barueri: Manole, 2008.

Ferraz Junior, Tercio Sampaio; Maranhão, Juliano Souza de Albuquerque. Função pragmática da justiça na hermenêutica jurídica: lógica "do" ou "no" direito? Revista do Instituto de Hermenêutica Jurídica - A filosofia "no" direito e a filosofia "do" direito. n. 5. vol. I. p. 273-318. Porto Alegre: Instituto de Hermenêutica Jurídica, 2007.

Houaiss, Antônio. Dicionário Houaiss da língua portuguesa. Rio de Janeiro: Objetiva, 2001.

Larenz, Karl. Metodologia da ciência do direito. 3. ed. Lisboa: Fundação Calouste Gulbenkian, 1997.

Lessa, Pedro. Estudos de filosofia do direito. 2. ed. Campinas: Bookseller, 2002.

Mancuso, Rodolfo de Camargo. Súmula vinculante e a EC n. 45/2004. In: ARRuda Alvim Wambier, Teresa et al (coords.). Reforma do Judiciário - Primeiras reflexões sobre a Emenda Constitucional n. 45/2004. São Paulo: Ed. RT, 2005.

Maranhão, Juliano Souza de Albuquerque. Some operators for refinement of normative systems. In: Verheij, Bart; Lodder, Arno R.; Loul, Ronald P.; MuntjewerfF, Antoinette J. (eds.). Legal knowledge and information systems, frontiers in artificial intelligence and applications. Amsterdam: IOS Press, 2001. 
Martins, Ives Gandra da Silva. O STF e a estabilidade das instituições. Folha de S. Paulo, Cad. Opinião, 16.09.2008.

Maximiliano, Carlos. Hermenêutica e aplicação do direito. 9. ed. Rio de Janeiro: Forense, 1979.

Mendes, Gilmar; PJlug, Samantha Meyer. Passado e futuro da súmula vinculante: considerações à luz da emenda constitucional n. 45/2004. In: ReNAult, Sérgio Rabello Tamm; Bottins, Pierpaolo. Reforma do Judiciário - Comentários à Emenda Constitucional n. 45/2004. São Paulo: Saraiva, 2005.

Morato, Leonardo Lins. A reclamação e a sua finalidade para impor o respeito à súmula vinculante. In: Arruda Alvim Wambier, Teresa et al (coords.). Reforma do Judiciário - Primeiras reflexões sobre a Emenda Constitucional $n$. 45/2004. São Paulo: Ed. RT, 2005.

Nalini, José Renato. O Brasil precisa de súmula vinculante? Disponível em: [www.tj.ro.gov.br/emeron/sapem/2002/julho/1907/ARTIGOS/A01.htm]. Acesso em: 16.09.2006.

Nery Junior, Nelson. Teoria geral dos recursos. 6. ed. São Paulo: Ed. RT, 2004.

. Boa-fé objetiva e segurança jurídica. Eficácia da decisão judicial que altera jurisprudência anterior do mesmo tribunal superior. In: FERRAz JUNIOR, Tercio Sampaio; Carrazza, Roque Antonio; Nery Junior, Nelson. Efeito "ex nunc" e as decisões do STJ. Barueri: Manole, 2008.

; Nery, Rosa Maria de Andrade. Código de Processo Civil comentado e legislação extravagante. 10. ed. São Paulo: Ed. RT, 2007.

; Nery, Rosa Maria de Andrade. Código Civil comentado. 6. ed. São Paulo: Ed. RT, 2008.

; Nery, Rosa Maria de Andrade. Constituição Federal comentada e legislação constitucional. 2. ed. São Paulo: Ed. RT, 2009.

Oteiza, Eduardo. El problema de la uniformidad de la jurisprudencia en América Latina. Revista de Processo. vol. 136. p. 151-196. São Paulo: Ed. RT, jun. 2006.

Renault, Sérgio Rabello Tamm; Bottini, Pierpaolo (coords.). Reforma do Judiciário - Comentários à Emenda Constitucional n. 45/2004. São Paulo: Saraiva, 2005.

Sarney, José. O Supremo Tribunal Federal. Folha de S. Paulo, Cad. Opinião, 07.09.2008.

Shimura, Sérgio Seiji. Súmula vinculante. In: Arruda Alvim Wambier, Teresa (coord.) et al. Reforma do Judiciário - Primeiras reflexões sobre a Emenda Constitucional n. 45/2004. São Paulo: Ed. RT, 2005.

Silva, Evandro Lins e. Crise de hermenêutica e súmula vinculante. Disponível em: [http://campus.fortunecity.com/clemson/493/jus/m05-011.htm]. Acesso em: 16.09.2006.

SouzA, Marcelo Alves Dias de Souza. Do precedente judicial à súmula vinculante. 1. ed., 2. tir. Curitiba: Juruá, 2007. 
Tavares, André Ramos. Nova Lei da Súmula Vinculante: estudos e comentários à Lei 11.417 de 19.12.2006. São Paulo: Método, 2007.

Theodoro Júnior, Humberto. A onda reformista do direito positivo e suas implicações com o princípio da segurança pública. Revista de Processo. vol. 136. p. 32-57. São Paulo: Ed. RT, jun. 2006.

Torrinha, Francisco. Dicionário latino-português. 3. ed. Porto: Maranus, 1945.

Wambier, Luiz Rodrigues; Arruda Alvim Wambier, Teresa; Medina, José Miguel Garcia. Breves comentários à nova sistemática processual civil - Emenda Constitucional n. 45/2004 (Reforma do Judiciário), Leis 10.444/2002, 10.358/2001 e 10.352/2001. 3. ed. São Paulo: Ed. RT, 2005.

WieAcker, Franz. História do direito privado. 3. ed. Lisboa: Fundação Calouste Gulbenkian, 2004.

\section{Pesquisas do Editorial}

\section{Veja também Doutrina}

- Algumas questões a respeito da súmula vinculante e precedente judicial, de Guilherme Sarri Carreira - RePro 199/213;

- "Reforma do judiciário", celeridade do processo e as "súmulas vinculantes": considerações para uma análise crítica da EC 45/2004, de Daniel Favaretto Barbosa RePro 138/92;

- Súmula vinculante: solução ou retrocesso?, de José Carlos de Moraes Salles - RT 864/11;

- Súmula vinculante versus precedentes: notas para evitar alguns enganos, de Georges Abboud - RePro 165/218; e

- Súmulas vinculantes em terrae brasilis: necessitamos de uma "teoria para a elaboração de precedentes"?, de Lenio Luiz Streck - RBCCrim 78/284. 